\title{
FALSAFAH SAINS IBN AL-HAYTHAM DENGAN RUJUKAN KHAS KEPADA KITĀB THAMARAH AL-HIKMAH
}

IBN AL-HAYTHAM'S PHILOSOPHY OF SCIENCE WITH SPECIAL REFERENCE TO KITĀB THAMARAH AL-HIKMAH

\section{Usep Muhamad Ishaq*, Wan Mohd Nor Wan Daud}

Centre of Advanced Studies on Islam Science and Civilisation. Universiti Teknologi Malaysia (UTM). Kuala Lumpur. 54100. Malaysia.

Email: *usepmohamadishaq@gmail.com

\begin{abstract}
Khulasah
Ibn al-Haytham (w. 1038/9 M) setakat ini lebih dikenali sebagai seorang sarjana dalam bidang sains alam dan matematik. Karya-karya dalam bidang lain seperti falsafah telah hilang dan tidak dapat diperoleh. Oleh itu, kajian terhadap pemikirannya dalam bidang falsafah amnya dilakukan melalui pernyataanpernyataannya yang tertebar dalam karya-karya sains dan matematiknya ataupun melalui rujukan-rujukan sekunder dan tidak langsung. Amat sedikit kajian terhadap satu-satunya karya Ibn al-Haytham dalam bidang falsafah bertajuk Kitāb Thamarah al-Hikmah atau Maqālah 'an Thamarah al-Hikmah sejauh ini, padahal karya Ibn al-Haytham ini mengandungi segisegi falsafah yang amat penting untuk memahami pemikiran dan pandangan dalam falsafah secara am. Manuskrip daripada Kitāb Thamarah al-Hikmah berada di perpustakaan Köprülü Turki dengan nombor kumpulan manuskrip MS 1604 dan telah disunting oleh Abū Rīdah pada tahun 1991 untuk pertama kalinya. Makalah ini memperkenalkan karya Ibn alHaytham ini dan membincangkan beberapa segi falsafah, utamanya segi falsafah sainsnya mencakup segi matlamat penyelidikan alam tabii, segi-segi ontologi dan epistemologi utamanya tentang saluransaluran ilmu pengetahuan, dan kerangka-kerja
\end{abstract}


(framework) yang digunakan Ibn al-Haytham dalam penyelidikan alam tabii. Hasil penyelidikan mendapati bahawa dalam segi konsep-konsep asasnya, falsafah sains Ibn al-Haytham sejalan dengan pandangan alam Istām.

Kata kunci: Ibn al-Haytham, Kitāb Thamarah alHikmah, Maqālah 'an Thamarah al-Hikmah, falsafah sains, sains Islam.

\begin{abstract}
Ibn al-Haytham (d. 1038/9) is hirherto known merely as a scientist and mathematician. However, his works in other fields, such as in philosophy, is unavailable. Therefore, most of studies on his thought in philosophy were based only on his scattered excerpts in works on science and mathematics, or used secondary sources and indirect references. There has been little research done so far on his only surviving work known on philosophy Kitāb Thamarah alHikmah or Maqālah 'an Thamarah al-Hikmah; in fact, this work contains many philosophical aspects that are crucial to understand his thought and views on philosophy in general. The manuscript of Kitāb Thamarah al-Hikmah MS 1604 is held at Köprülü library Turkey and has been firstly edited in 1991. This paper introduces this work and discusses some philosophical aspects mainly on his philosophy of science, such as the purposes of studying nature, ontological, and epistemological aspects mainly on the channels of knowledge, and the framework used by Ibn al-Haytham in the study of natural phenomena. The study found that the fundamental concepts of his philosophy of science are in line with the worldview of Islām.
\end{abstract}

Keywords: Ibn al-Haytham, Kitāb Thamarah alHikmah, Maqālah 'an Thamarah al-Hikmah, philosophy of science, Islamic science. 


\section{Pendahuluan}

Ibn al-Haytham merupakan seorang sarjana Islām yang setakat ini lebih dikenali sebagai seorang ahli sains dan matematik. Kajian berkenaan aspek pemikirannya dalam bidang falsafah masih sangat kurang. Hal ini disebabkan kerana sulitnya menjumpai karya-karya Ibn al-Haytham yang secara khas membincangkan falsafah. Karyakaryanya yang masih ada saat ini terhad hanya dalam bidang sains alam tabii dan matematik. Oleh itu, umumnya kajian terhadap aspek falsafah dari pemikiran beliau saat ini cenderung ditumpukan melalui pernyataan-pernyataannya yang tertebar dalam pelbagai karyanya dalam sains dan matematik, ataupun dengan menggunakan rujukan-rujukan sekunder yang bukan merupakan pernyataan Ibn alHaytham secara langsung.

Meskipun kedua-dua jenis kaedah tersebut dapat digunakan, tetapi menumpukan pemikiran seseorang hanya melalui pernyataannya yang tertebar secara tidak tersusun akan sulit memperoleh gambaran pemikirannya secara utuh, manakala memberi tumpuan kajian pemikiran seorang tokoh terhadap rujukan-rujukan sekunder berpeluang lebih besar untuk menjauhkan hasil kajian dari objektiviti penelitian.

Oleh itu, kajian ini diketengahkan untuk meninjau semula dan menyelidiki karya-karya Ibn al-Haytham untuk memperoleh karyanya dalam bidang yang berkaitan dengan falsafah, khasnya falsafah sainsnya. Dan melakukan kajian pendahuluan kepada pemikiran falsafah yang ada di dalamnya.

\section{Tinjauan Ringkas Karya-Karya Ibn al-Haytham}

Abū 'Alī al-Ḥasan ibn al-Hasan Ibn al-Haytham lahir di Basrah pada sekitar tahun 354 H/965 M. Beliau lebih dikenali di Eropah dengan nama 'Alhazen' yang berasal dari nama 'al-Hasan'. Sedangkan nama 'al-Haytham' adalah nama datuknya, namun sebutan ini sudah sangat 
lekat dengan dirinya sehingga beliau dikenali pula sebagai Ibn al-Haytham di dunia Islām.

Pelbagai kajian historiografi mengenai Ibn alHaytham kebanyakannya merujuk kepada lima laporan sejarah (historical accounts) para ahli sejarah yang kesemuanya hidup lebih dari seratus tahun dari masa Ibn alHaytham, iaitu al-Bayhaqī (w. 1170), ${ }^{1}$ al-Qifțī (w. 1248), ${ }^{2}$ Ibn Usaybi 'ah (w. 1270), ${ }^{3}$ Ibn al-'Ibrī (w. 1286), ${ }^{4}$ dan juga laporan singkat tentang Ibn al-Haytham oleh Șāid alAndalusī. ${ }^{5}$ Meskipun demikian, laporan Ibn Usaybi'ah mengandungi salinan dari riwayat hidup yang ditulis oleh Ibn al-Haytham sendiri dan merupakan catatan paling lengkap di antara kelima-lima laporan tersebut.

Catatan biografi Ibn al-Haytham oleh Ibn Usaybi 'ah

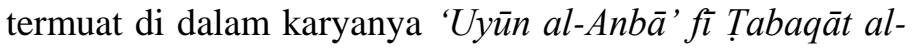
Ațibba ', yang juga merangkumi laporan al-Qifți dan Ibn al'Ibrī. Selain mengandungi riwayat hidup singkat Ibn alHaytham, di dalamnya terkandung senarai karya-karya Ibn al-Haytham, sama ada yang disebutkan oleh Ibn alHaytham sendiri ataupun yang disebutkan oleh Ibn Usaybi ah. Senarai tersebut terdiri dari tiga bahagian menurut kurun waktu penulisan: ${ }^{6}$ senarai pertama, disebut sebagai senarai I, adalah senarai karya yang ditulis sendiri oleh Ibn al-Haytham dalam autobiografinya yang dinukil di dalam karya Ibn Abī Usaybi'ah tersebut.

${ }^{1}$ Zahīr al-Dīn al-Bayhaqī, Tatimmah al-Șiwān al-Hikmah (Beirut: Dār al-Fikr al-Lubnānī, 1994).

2 Jamāl al-Dīn Abī al-Ḥasan 'Alī ibn Yusūf al-Qifṭi, Tārikh al-Hukamā', ed. Julius Lippert (Leipzig: Dieterich'sche Verlagsbuchhandlung (Theodor Weicher), 1903).

${ }^{3}$ Ibn Abi Usaybi ah, 'Uyūn al-Anbā' fì Tabaqāt al-Ațibbā' (Beirut: Dar al-Kutūb al-'Ilmiyyah, 1998). Seterusnya disebut sebagai 'Uyūn.

4 Abū Farrāj ibn Harūn ibn al-'Ibrī, Tārikh Mukhtașar al-Duwal, ed. Anțūn Șālhạn̄ī (Beirut: al-Maṭba'ah al-Kātūlīkiyyah, 1958).

5 Șāid al-Andalusī, Tabaqāt al-Umam, terj. ed. Sema' an I. Salem dan Alok Kumar, Science in the Medieval World "Book of the Catagorie of Nations" (Austin Tex:University of Texas Press, 1991).

${ }^{6}$ Ibn Usaybi 'ah, 'Uyūn, 505-515. 
Selain itu Ibn Abī Usaybi'ah menambahkan dua senarai lainnya, disebut sebagai senarai II dan III, yang memiliki cakupan waktu berbeza. Senarai I adalah karya Ibn al-Haytham yang ditulis sehingga bulan Dhū al-Hijjah $417 \mathrm{H}$ atau sekitar bulan Februari 1027M yang memuat 25 karya dalam bidang matematik dan 44 karya dalam falsafah dan sains, di mana karya ke-44 adalah komentarnya terhadap 30 karya Galen dalam ilmu perubatan, sehingga jumlah sub-total karyanya pada Senarai I adalah 69 karya.

Senarai II merupakan karya Ibn al-Haytham antara Dhū al-Hijjah 417H/Februari 1027M sehingga bulan Jamādī al-Ākhirah 419H/Julai 1028M yang mengandungi 21 karya dalam pelbagai bidang iaitu matematik, sains, ilmu kalām, perubatan, dan astronomi. Senarai III merupakan senarai karya Ibn al-Haytham hingga akhir tahun 429H/1038M yang mengandungi 92 karya. Karyakarya ini merangkumi pelbagai tajuk termasuk matematik, mantik, astronomi, optik, muzik, persuratan dan ilmu akhlak.

Karya-karyanya dalam bidang keagamaan (teologi), falsafah, metafizik dan kalām banyak terkandung di dalam senarai I dan II. Namun, hampir keseluruhannya tidak diketahui keberadaannya sehingga masa kini. Ibn alHaytham menyebutkan bahawa banyak karyanya yang jatuh ke tangan beberapa orang di Basrah dan Ahwāz dan kemudian tidak dijumpainya lagi. ${ }^{7}$

Secara keseluruhan jumlah karya Ibn al-Haytham dalam ketiga-tiga senarai tersebut adalah 182 buah karya. Dari lebih kurang 182 karya yang ditulis Ibn al-Haytham semasa hidupnya, hanya lebih kurang 61 karya yang saat ini diketahui masih wujud dan tersebar di pelbagai tempat seperti di Jerman, Mesir, Perancis, Rom, Leiden Belanda, Turki dan lain-lain, ${ }^{8}$ di mana sebahagian masih dalam

\footnotetext{
${ }^{7}$ Ibid., 512.

8 Carl Brockelmann, Geschichte Der Arabischen Litteratur Vol. I (Leiden: E.J. Brill, 1943), 617-619.
} 
bentuk manuskrip dan sebahagian lainnya telah disunting dan diterbitkan.

Sebahagian besar karyanya yang masih wujud sehingga saat ini secara statistik, dalam bidang sains tabii dan matematik adalah lebih kurang $41 \%$, khas dalam bidang astronomi $21 \%$, metafizik termasuk yang berkaitan dengan pokok-pokok agama $18 \%$, dalam ilmu mantik masing-masing $15 \%$. Karyanya selain itu berkenaan dengan perubatan, persuratan, politik dan perakaunan. Dari taburan statistik karyanya dalam pelbagai bidang keilmuan tampaklah jelas bahawa tiadalah tepat apabila dikatakan bahawa Ibn al-Haytham hanyalah seorang spesialis sempit dalam bidang sains empirikal atau ahli matematik sahaja. Sebab secara amnya, beliau sebenarnya telah banyak juga mengkaji dan menulis dalam bidang-bidang keilmuan lain seperti metafizik dan falsafah sebagaimana sarjana Muslim di masa lalu.

Selain itu, terdapat beberapa karya Ibn al-Haytham yang seakan tidak tersenarai dalam senarai karya Ibn alHaytham di dalam 'Uyūn, di antaranya adalah karyanya yang bertajuk Thamarah al-Hikmah. Karya ini diketahui merupakan karya Ibn al-Haytham di antaranya disebutkan oleh Henry Corbin (w. 1978), tetapi saat ini belum dilakukan pengkajian secara luas. Corbin menyatakan:

"He was an important influence in the fields of celestial physics, astronomy, optics, and the science of perspective. His philosophical presuppositions are still to be systematically examined; he was deeply learned in philosophical culture, for he had read Galen and Aristotle carefully, but his own philosophical work is unfortunately lost, or else remains 
unedited, like the Kitab Thamarat al-Hikmah, 'the fruits of philosophy'.",9

Thamarah al-Hikmah setakat ini merupakan satusatunya karya Ibn al-Haytham yang masih wujud sehingga masa kini yang secara khas membincangkan masalah falsafah. Akan tetapi para pengkaji falsafah sains Ibn alHaytham tampaknya belum menjadikan karya tersebut sebagai bahan rujukan bagi pemikiran falsafah Ibn alHaytham, kerana sebagaimana dinyatakan Henry Corbin ia dianggap telah hilang atau belum disunting dan diterbitkan pada saat itu. ${ }^{10}$

Sememangnya ia baru disunting pertama kalinya pada sekitar tahun 1991 tetapi masih belum tersebar secara luas. Tidak ditemui tajuk Thamarah al-Hikmah pada senarai karya Ibn al-Haytham di dalam ' Uyūn mungkin disebabkan adanya perbezaan tajuk dengan sebuah karya dengan tajuk Kitāb fì al-Madkhāl ilà al-Umür al-Handasah yang berada pada senarai I, atau kemungkinan lainnya bahawa ia merupakan karya Ibn al-Haytham yang dianggap hilang bersama karya lainnya sebagaimana disebutkan Ibn alHaytam. ${ }^{11}$

\section{Tinjauan Ringkas Tentang Kitāb Thamarah al-Hikmah} Naskah manuskrip Kitāb Thamarah al-Hikmah dapat ditemukan dalam katalog perpustakaan Köprülü Turki dengan nombor kumpulan manuskrip MS 1604. ${ }^{12}$ Manuskrip Kitāb Thamarah al-Hikmah terdapat pada salah satu bahagian dari kumpulan manuskrip tersebut dan

\footnotetext{
${ }^{9}$ Henry Corbin, History of Islamic Philosophy, terj. Liadain Serrard dan Philip Sherrard (London: Kegan Paul International, 1993), 149.

${ }^{10} \mathrm{Ibid}$.

${ }^{11}$ Muhammad 'Abd al-Hādī Abū Rīdah, "Preface," dalam Maqālah 'an Thamarah al-Hikmah (Cairo: al-Maktabāt al-Miṣriyyah bi al-Qāhirah, 1991), tanpa nombor hlm.

12 Ramazan Şeşen et. al., Catalogue of Manuscripts in the Köprülü Library Vol. II (Istanbul: Research Centre For Islamic History, Art and Culture, 1986), 330-331.
} 
terkumpul bersama dengan karya para sarjana lain. ${ }^{13}$ Manuskrip Kitāb Thamarah al-Hikmah karya Ibn alHaytham telah disunting pertama kalinya dan diberi pengantar oleh Muhammad 'Abd al-Ḥādī Abū Rīdah (1991), dan beberapa tahun kemudian juga disunting oleh 'Ammār Jam'î al-Țālibī (1998) yang kedua-duanya berdasarkan pada naskah Köprülü MS 1604 tersebut. ${ }^{14}$

Muhammad 'Abd al-Hādī Abū Rīdah menyebutkan bahawa penyebutan lafaz 'Kitāb' pada karya ini bukan berasal dari Ibn al-Haytham sendiri, tetapi merupakan tambahan dari penyalinnya. ${ }^{15}$ Oleh itu, Abū Rīdah menyebut karya ini sebagai Maqālah 'an Thamarah alHikmah. Bahagian ilmu jiwa dari karya Ibn al-Haytham tersebut telah diringkas oleh Jum'ah Sayyid Yūsuf (1996). ${ }^{16}$ Meskipun demikian karya ini tampaknya belum mendapatkan perhatian yang cukup khasnya dari para pengkaji falsafah Ibn al-Haytham.

Maqālah atau Kitāb Thamarah al-Hikmah, tiada lagi diragui merupakan karya Ibn al-Haytham meskipun ia tiada terdapat dalam senarai karyanya yang dimuat dalam 'Uyūn. Beberapa alasan yang mendukung hal ini adalah: Pertama, sebagaimana telah dihuraikan sebelum ini bahawa tidak termasuknya tajuk Thamarah al-Hikmah dalam senarai tajuk karya-karya Ibn al-Haytham dalam 'Uyūn mungkin

13 Manuskrip "Kitāb Thamarah al-Hikmah" berada dalam kumpulan manuskrip MS 1604 di perpustakaan Köprülü, Istanbul, Turki. Ia bersama manuskrip "Iḥșā al-'Ulūm", "Risālah 'Uyūn al-Masā'il", "Risālah Mabādī' al-Ashyā̄ wa Marātibihā", karya al-Farāb̄̄, dan lain-lain. Manuskrip Thamarah al-Hikmah berada pada halaman 4159, ditulis dengan gaya naskhī yang masih dapat dibaca dengan jelas.

14 'Ammār Jam'ì al-Ṭālibī, "Kitāb Thamarah al-Ḥikmah li Ibn alHaytham Dirāsah wa Taḥqīq," dalam Majallah Majma 'al-Lughah al'Arabiyah bi Dimashq April 73 No. 2 (Damaskus: Majma' al-Lughah al-'Arabiyah bi Dimashq, 1998), 261-310.

${ }^{15}$ Abū Rīdah, "Preface", tanpa nombor hlm.

${ }^{16}$ Jum 'ah Sayyid Yūsuf, "Ibn al-Haytham," dalam 'Ilm al-Nafs fī Turath al-Islāmì Vol. 2 (Kaherah: Al-Ma had al-'Alamì li al-Fikr al-Islāmī, 1996), 9-14. 
disebabkan adanya perbezaan penyebutan dengan tajuk karyanya yang lain iaitu Kitāb fi al-Madkhāl ilā al-Umūr al-Handasah yang berada pada senarai I nombor 17. Alasannya, senarai tajuk karya-karya Ibn al-Haytham yang ada di dalamnya sebenarnya tidak selalunya menunjuk kepada nama tajuk sebuah karya, tetapi kadang-kadang merupakan kandungan umum karya tersebut.

Misalnya Ibn al-Haytham menyatakan bahawa ia telah menulis "Buku yang aku kumpulan di dalamnya pokokpokok geometri dan aritmetik daripada buku Euclid dan Appolonius, dan aku kelompokkan di dalamnya pokokpokoknya dan pembahagiannya, serta aku buktikan daripadanya dengan bukti yang tersusun daripada masalahmasalah yang berkaitan dengan matematik, yang terindera, dan mantik." Penjelasan Ibn al-Haytham tersebut lebih merupakan huraian tentang kandungan buku daripada benar-benar merujuk pada suatu tajuk buku, demikian juga beberapa buku lainnya dalam senarai tersebut.

Petunjuk terhadap hal ini adalah di dalam Thamarah al-Hikmah sendiri, iaitu Ibn al-Haytham telah menyebutkan bahawa kitab tersebut dimaksudkan sebagai pendahuluan kepada ilmu geometri: "madkhalan ilà al-șinā'ah alhandasah,"17 yang memiliki keserupaan dengan huraian suatu karya bertajuk Kitāb fì al-Madkhāl ilā al-Umūr alHandasah. Dengan demikian, sangatlah mungkin bahawa Kitāb Thamarah al-Hikmah sememangnya termuat dalam senarai 'Uyūn dengan tajuk berbeza tetapi merujuk pada karya yang sama iaitu Kitāb fì al-Madkhāl ilā al-Umūr alHandasah tersebut.

Kemungkinan lainnya adalah sebagaimana dinyatakan oleh Abū Rīdah, bahawa Kitāb Thamarah al-Hikmah boleh jadi termasuk ke dalam sejumlah karya Ibn al-Haytham yang dianggap hilang sebagaimana dinyatakan Ibn alHaytham sendiri bahwa banyak karyanya yang telah hilang

17 'Ammār, "Kitāb Thamarah al-Ḥikmah li Ibn al-Haytham," 264. 
sebagaimana dinyatakan di dalam `Uyūn ketika ia berada di Basrah dan Ahwaz. ${ }^{18}$

Kedua, karya tersebut diberi tajuk Kitāb Thamarah alHikmah li Ibn al-Haytham, dan dimulakan dengan "qāla Abū 'Alī al-Hasan Ibn al-Haytham rahimahu'Llāh" sebagaimana karya-karya Ibn al-Haytham lainnya, yang secara pasti merujuk kepada nama Ibn al-Haytham yang dimaksudkan.

Ketiga, kandungan dalam Kitāb Thamarah al-Hikmah tidak bercanggah isi kandungannya dengan karya-karyanya yang lain, malah justeru selaras dengannya. Sebagai contoh, ungkapan-ungkapan dan pengistilahan yang serupa adalah istilah-istilah penting dalam autobiografi beliau seperti 'thamrah hādhā al- 'ulūm', 'mahd al-khayr', 'ilm al-haqq wa al- 'amal bi al- 'adl', dan lain-lain ditemukan juga dalam Kitāb Thamarah al-Hikmah. Juga demikian pernyataannya tentang tujuan mempelajari alam semesta adalah untuk mengetahui kebijaksanaan Allāh Ta'ālā (hikmah Allāh ta' ālāa), ${ }^{19}$ ditemukan juga dalam Kitāb alManazir sebagai hikmah al-șān̄ ${ }^{20}$

Demikian pula ada kesamaan ungkapan dalam karyanya yang lain tentang kebenaran iaitu ia diinginkan kerana dirinya sendiri dan bukan kerana selainnya:

"Kebenaran itu diinginkan kerana dirinya, dan setiap yang diinginkan kerana dirinya

${ }^{18}$ Abū Rīdah, "Preface, tanpa nombor hlm; rujuk juga: Ibn Usaybi ‘ah, 'Uȳun, 512.

19 Ibn al-Haytham, "Kitāb Thamarah al-Hikmah li Ibn al-Haytham Dirāsah wa Taḥqīq," dalam Majallah Majma 'al-Lughah al- 'Arabiyah bi Dimashq April 73 No. 2 (Damsyik: Majma' al-Lughah al'Arabiyah bi Dimashq, 1998), (45); selanjutnya disingkat sebagai $M T H H$ (nombor perenggan).

20 Ibn al-Haytham, Kitāb al-Manāzir li'l-Hasan Ibn al-Haytham, ed. A.I. Sabra (Kuwait: The National Council for Culture, Arts and Letter, 1983), 187-188 \{A.I. Sabra, Ibn Al-Haytham Optics Books I-III On Direct Vision, vol.1 (2 vols.) (London: The Warburg Institute University of London, 1989), 103 \}, seterusnya disingkat sebagai $K M$; rujuk juga: $K M, 189\{104\}$. 
pencarinya tidak memerlukan selain daripada keberadaannya." 21

Ungkapan ini juga dapat ditemukan dalam Kitāb Thamarah al-Hikmah (MTHH) ketika Ibn al-Haytham menghubungkan konsep kebahagiaan dengan meraih pengetahuan al-hikmah, iaitu pengetahuan tentang kebenaran:

"Manusia dengan daya akalnya menunjukkan bahawa dia dipersiapkan untuk mencari kebahagiaan (al-sa'ádah), iaitu perolehan kebaikan yang hakiki (al-khayr 'alā alhaqiqqah). Kebaikan yang hakiki adalah sesuatu yang diinginkan kerana dirinya sendiri... Sesuatu yang diinginkan kerana dirinya sendiri, adalah ia yang tiada satu halpun dalam dirinya yang tiada ia sukai. Oleh itu kebahagiaan adalah perolehan sesuatu yang dicari yang tiada satu hal pun pada dirinya yang tiada disukai. Adapun keterbebasan daripada selain kepedihan, adalah apa yang dikhaskan pada haiwan rasional sahaja, dan ia adalah ilmu (al-'ilm). ... Ilmu tentang setiap yang kebenaran dan setiap amalan yang memberi manfaat, kedua-duanya adalah dua bahagian daripada al-hikmah; dengan demikian memperoleh al-hikmah adalah keterbebasan daripada selain kepedihan; dan bahawa keterbebasan tersebut diinginkan melalui keberadaan lawannya dan ketiadaannya seluruhnya, dan tidak ada sesuatu hal pun yang tak disukai daripadanya." 22

${ }^{21}$ Ibn al-Haytham, al-Shukūk 'alā Bațlamyūs li'l-Hasan ibn al-Haytham, ed. A.I. Sabra dan N. Shehaby (Kaherah: Maṭba'ah Dār al-Kutūb, 1971), 3-4. Selanjutnya disingkat sebagai $S B$.

${ }^{22}$ MTHH (25)-(28). 
Abū Rīdah sendiri sebagai penyunting pertama manuskrip ini menyatakan bahawa sememangnya ia adalah karya dari Ibn al-Haytham: ${ }^{23}$

"I have known and used this precious treatise more than twenty years ago, without being sure that it belongs to Ibn al-Haytham. The comparison, however, between the style, the characteristic way of expression and even words and concepts of Ibn al-Haytham in this treatise, in what we read in his autobiography (see Ibn Abī Ușaybi'ah) and in the introduction of his book "Solution of Difficulties in Euclid's Principles", contributed to my conviction that we read in it something of our great scientist."

Alasan keempat adalah pernyataan para sarjana seperti Henry Corbin, Abū Rīdah, 'Ammār Jam'ī al-Ṭālibī, Jum 'ah Sayyid Yūsuf, dan lain-lain yang menyatakan bahawa ia sememangnya merupakan karya Ibn al-Haytham.

Kitāb Thamarah al-Hikmah atau Maqālah 'an Thamarah al-Hikmah sebenarnya ditujukan sebagai muqaddimah kepada ilmu matematik bagi para pemula sebagai tahapan untuk mempelajari al-Hikmah atau falsafah Islam. ${ }^{24}$ Meskipun demikian, di dalamnya Ibn alHaytham berusaha menjelaskan pelbagai aspek falsafah, termasuklah di dalamnya penggolongan ilmu (classification) dan aksiologi yang berkaitan dengan konsep-konsep akhlak, kebahagiaan, dan lain-lain.

Secara amnya isi kandungan dari Kitāb Thamarah alHikmah merangkumi perbincangan-perbincangan tentang: ta'rif dari falsafah (al-hikmah), pokok-pokok dan klasifikasi ilmu atau falsafah (al-hikmah), ilmu jiwa (psikologi) dan huraian fakulti-fakulti manusia, konsep kebahagiaan, konsep Manusia Sempurna (al-insān al-

\footnotetext{
${ }^{23}$ Abū Rīdah, "Preface", tanpa nombor hlm.

${ }^{24}$ Ibn al-Haytham, "Kitāb Thamarah al-Hikmah", 282-310.
} 
tāmm), pendahuluan kepada ilmu geometri dan tentang penghujahan dalam ilmu matematik. Dalam makalah ini, hanya akan dikaji beberapa segi berkenaan dengan ilmu jiwa (psikologi) dan hubung-kaitnya dengan konsep kebahagiaan menurut Ibn al-Haytham.

\section{Matlamat Penyelidikan Alam Tabii (Sains)}

Menurut Ibn al-Haytham, khasnya dalam $M T H H$, sains dalam pengertian penyelidikan terhadap alam tabii tiada dapat diasingkan dari keseluruhan bangunan al-hikmah. Alhikmah kesempurnaanya mestilah diraih melalui beberapa tahapan yang merangkumi tiga bahagian, iaitu: ilmu-ilmu matematik (riyāẹiyyāt), ilmu-ilmu alam (tabi 'ìyyāt), dan ilmu yang berkaitan dengan masalah metafizik (ilāhiyyāt). ${ }^{25}$

Ibn al-Haytham kemudian menjelaskan bahawa ilmuilmu matematik adalah ilmu yang membahas bentuk dan angka, sedangkan ilmu-ilmu alam adalah menyelidiki pelbagai perilaku dan sifat mawjud yang ada (mawjūdāt) berserta alasan-alasan dan dasar-dasarnya; sedangkan ilmu metafizik adalah ilmu di luar alam tabii (khārij al-samā'), yang juga merangkumi ilmu tentang Pencipta yang digambarkan sebagai pelaku awal (al-fā ìl al-awwal), yang awal segala permulaan (mabda' al-mabādi'), yang pertama daripada segala permulaan (awwal al-awā $i l)$, dan segala sifat dan Perbuatan yang layak bagi-Nya. ${ }^{26}$

Oleh itu, jelaslah bahwa dalam pandangan Ibn alHaytham penyelidikan terhadap alam tabii, yang disebut saat ini sebagai sains, merupakan suatu bahagian yang tiada dapat diasingkan dari keseluruhan bangunan al-hikmah yang memiliki matlamat tertentu. Ibn al-Haytham memberi ta rif al-hikmah sebagai:

$$
\text { الحكمة علم كل حق وعمل كل نافع }
$$

${ }^{25}$ MTHH (30), rujuk juga dalam autobiogarfinya di dalam 'Uyūn, 508.

${ }^{26} \mathrm{MTHH}(30)$. 
"Al-hikmah adalah pengetahuan tentang setiap yang benar dan perbuatan setiap yang bermanfaat." 27

Dari ta rif tersebut, maka al-hikmah memiliki dua segi, yakni segi akliah iaitu yang bersifat teoretikal atau keilmuan, dan segi kedua adalah amaliah atau praktikal. Kedua-dua segi dari pengetahuan ini bukanlah matlamat akhir dari al-hikmah itu sendiri tetapi sarana untuk mencapai matlamat tertinggi menjadi seorang manusia yang sempurna yang dapat diraih ketika dia telah memperolehi kebaikan yang murni (khayr mahḍ̄), iaitu kebaikan yang dilakukan kerana kebaikan itu sendiri sebagaimana yang beliau nyatakan:

"Oleh itu orang-orang awam memerlukan pada al-hikmah kenabian (al-hikmah al-nabawiyah) kerana seorang yang memiliki al-hikmah (hakim) terdorong untuk berbuat kebaikan kerana kebaikan itu sendiri, bukan untuk mencari imbalan daripadanya, dan mencegah dirinya daripada perbuatan buruk kerana keburukan itu sendiri bukan kerana takut akan balasan daripadanya." 28

Pada tahapan ini seorang manusia telah berjaya meneladani perbuatan-perbuatan dan sifat Tuhan yang baik dan agung. Oleh itulah Ibn al-Haytham memberikan ta rif kedua daripada hikmah iaitu:

$$
\begin{aligned}
& \text { الحكمة هي التشبّه بالله تعالى ذكره في أفعاله بمبلغ طاقة } \\
& \text { الإنسان }
\end{aligned}
$$

${ }^{27}$ MTHH (1).

${ }^{28} \mathrm{MTHH}(46)$. 
"Al-hikmah iaitu menyerupai nama-nama Allāh Ta'alā dalam perbuatan-perbuatanNya dengan kadar kemampuan manusia." ${ }^{29}$

Ibn al-Haytham menyatakan bahwa seorang manusia sempurna (al-insān al-tāmm) adalah manusia yang telah memiliki al-hikmah di dalam dirinya:

"Kerana itu manusia yang tidak memiliki alhikmah adalah manusia yang kurang, kerana ia tidak terbezakan haiwan yang tidak rasional, kerana dikhaskan akal baginya. Manusia yang memiliki al-hikmah (al-insān al-ḥakīm) adalah manusia yang sebenarnya, maksudku dengan hal tersebut adalah manusia yang sempurna (alinsān al-tāmm), kerana ia berbeza daripada haiwan yang tidak rasional (al-hayawān laysa nātiq) kerana dikhusukan baginya akal."30

Lebih jauh, Ibn al-Haytham menginginkan agar segala upayanya dalam mempelajari ilmu pengetahuan dapat mengangkat dirinya untuk menjadi orang-orang yang bertakwa, beliau menyatakan:

"Dan aku akan menjelaskan apa yang telah aku susun dalam tiga hal pokok itu supaya (orangorang) memahami tempatku dan perhatianku dalam mencari kebenaran dan kegairahanku untuk memahaminya, dan aku diketahui hakikatnya yang aku sebutkan daripadanya merupakan penolakan diriku terhadap keserupaan dengan orang awam, rakyat yang bodoh dan (agar dapat) mengangkat (diriku) untuk dapat menyerupai para wali Allāh (awliya $\bar{a}$ Allāh) yang terpilih dan orang-orang bertakwa (al-atqiȳa)." ${ }^{\prime 31}$

\footnotetext{
${ }^{29} \mathrm{MTHH}(31)$.

${ }^{30}$ MTHH (28)-(29).

${ }^{31}$ Ibn Usaybi'ah, 'Uyūn, 508.
} 
Dalam autobiografinya, beliau menyatakan bahawa matlamatnya mencari kebenaran dalam ilmu pengetahuan iaitu agar dapat lebih dekat (qurbah) kepada Allah sehingga dapat mencapai keriḍaanNya sehingga meraih darjat takwa:

"...dan kemahuanku mendorongku untuk mencapai pemikiran yang akan mendekatkan (diri) kepada Allah -agunglah pujian kepadaNya- (al-qurbah ilā Allāh) yang dapat memenuhi keridhaanNya, dan petunjuk kepada ketaatan dan ketakwaan kepadaNya.",32

Beliau juga menyatakan bahawa buah daripada ilmu adalah ilmu yang benar dan tercermin dalam perbuatan yang adil agar terbebas daripada kepayahan di dunia dan di akhirat:

"Buah daripada ilmu tersebut adalah pengetahuan yang benar dan amal perbuatan yang adil dalam seluruh urusan duniawi; Dan keadilan adalah kebaikan yang murni di mana yang melakukannya akan terbebas daripada kepayahan alam duniawi dan kenikmatan ukhrawi yang tinggi dan mengambil kesulitan apa yang layak baginya daripada hal itu waktu yang tertentu dan terbatas di negeri dunia, dan abadinya kehidupan yang nikmat di negeri akhirat. Dan kepada Allāh Ta'ālā aku mengharap keberhasilanku terhadap apa yang telah aku raih kerananya, dan aku mendekat kepadanya." 33

Oleh itu, jelaslah bahawa bagi Ibn al-Haytham alam tabii tidaklah diselidiki untuk keperluan-keperluan praktikal semata-mata, tetapi terdapat kemuncak matlamat yang lebih tinggi dari keduanya, iaitu menjadi seorang manusia yang sempurna.

${ }^{32}$ Ibid., 506.

${ }^{33}$ Ibid., 513. 
Di samping matlamat-matlamat yang bersifat spiritual dan metafizikal di atas, Ibn al-Haytham menjelaskan pula matlamat-matlamat penyelidikannya yang ilmiah dan akademik. Sekurang-kurangnya ada empat latar belakang dan matlamat lain dalam penyelidikan ilmiahnya. Di antara latar belakang yang menjadi masalah saintifik baginya adalah: untuk memperbetulkan konsep-konsep yang keliru, terutama daripada peninggalan para saintis dan ahli matematik Yunani; ${ }^{34}$ menyelesaikan percanggahan dan perbezaan pendapat yang biasanya terjadi semenjak masa Yunani antara ahli falsafah alam (golongan saintis) dengan para ahli matematik; ${ }^{35}$ memberi tambahan pada konsepkonsep yang dianggapnya kurang; berusaha untuk memberi hujah pada hipotesis yang belum diberikan bukti atau memberi hujah-hujah baru; ${ }^{36}$ matlamat yang bersifat

${ }^{34}$ Ibn al-Haytham,. "Risālah Aḍ̂ā' al-Kawākib," dalam Majmū 'alRasā 'il li al-Hasan ibn al-Hasan Ibn al Haytham (Hyderabad: Dā' irah al-Ma'ārif al-'Uthmānīyah, 1938; repr., Frankfurt: Institute for the History of Arabic-Islamic Science at the Johann Wolfgang Goethe University, 1998), 2, \{M.F. Quraishi dan J. Baarman, "Discourse on Light," dalam Ibn al-Haytham Proceedings of the Celebrations of 1000th Anniversary Hamdard National Foundation Pakistan (Karachi: Hamdard Academy, 1969), 221 \}; rujuk juga: Kamāluddīn al-Fārisī, Kitāb Tanqiḥ al-Manāzir lidhawi'l-Abșār wa al-Bașā ir vol. 2 (Hyderabad: Dā' irah al-Ma'ārif al-'Uthmānīyah, 1348 A.H.), 358.

${ }^{35} K M, 160\{82\}$; rujuk juga: $R M, 2\{224\}$; rujuk juga: Ibn al-Haytham, "Risālah fì al-Daw'," dalam Majmū' al-Rasā'il li-l-Hasan ibn alHasan Ibn al Haytham (Hyderabad: Dā'irah al-Ma'ārif al'Uthmānīyah, 1938; repr., Frankfurt: Institute for the History of Arabic-Islamic Science at the Johann Wolfgang Goethe University, 1998), 17-18 \{M.F. Quraishi and J. Baarman, "Discourse on Light," dalam Ibn al-Haytham Proceedings of The Celebrations of 1000th Anniversary Hamdard National Foundation Pakistan (Karachi: Hamdard Academy, 1969), 278-279\}.

36 Ibn al-Haytham, "Risālah fī Khawāṣṣ al-Muthallath min Jihat al'Amūd" dalam Majmū' al-Rasā'il li-l-Hasan ibn al-Hasan Ibn al Haytham (Hyderabad: Dā' irah al-Ma'ārif al-'Uthmānīyah, 1938), 3; \{F.A. Shamsi, "Properties of Triangles In Respect of Perpendiculars" dalam Ibn al-Haytham Proceedings of The Celebrations of 1000th 
akademik iaitu untuk tujuan pendidikan dan panduan praktikal, khasnya kepada para pelajar pemula.

Selain itu, matlamat lain dalam penyelidikan ilmiahnya adalah bersifat kegunaan (practical), sama ada untuk keperluan kehidupan keduniaan mahupun keperluan peribadatan-keagamaan. Ibn al-Haytham menyatakan bahawa salah satu matlamatnya mencari ilmu adalah untuk memberi manfaat dan sebagai bekal dirinya di hari tua:

"Sesungguhnya maksudku dan matlamatku dalam meninggalkan apa yang aku sudah dan sedang tinggalkan daripada buku-buku itu adalah untuk salah satu diantara dua hal apakah ia memberi manfaat kepada orang yang mengambil manfaat daripadanya, memberi maklumat baginya memberi manfaat bagi diriku sebagai latihan mental, di mana aku menikmati diriku pada saat aku menulisnya dan aku akan melakukannya sebagai peninggalan bagi masa tuaku." 37

Dengan demikian ia bukan suatu pragmatisme ataupun dualisme, tetapi berlandaskan asas memberi manfaat yang berdasarkan prinsip tawhìd. Dorongan keagamaan ini tercermin dalam pelbagai karyanya, misalnya daripada beberapa karyanya yang diperuntukkan sebagai panduan untuk menentukan arah kiblat dan keperluan agama lainnya. ${ }^{38}$

Anniversary Hamdard National Foundation Pakistan (Karachi: Hamdard Academy, 1969), 230\}, Seterusnya disingkat sebagai $R K M J U$; rujuk juga: $K M, 63\{6\}$.

${ }^{37}$ Ibn Usaybi'ah, 'Uyūn,508.

38 Juga dalam beberapa karyanya yang disebutkan dalam 'Uyūn: Maqālah fì Istikhrāj Samt al-Qiblah fì Jamī’al-Maskūnah (Risālah tentang Cara Memperoleh Arah Kiblat dari Seluruh Tempat), Maqālah fìmā Tad' $\bar{u}$ Ilayhi Hājah al-Umūr al-Shar'iyyah min alUmūr al-Handasiyyah (Makalah Perkara-Perkara yang di dalamnya Urusan Sharī'ah memerlukan kepada Ilmu Geometri dan yang tidak Memerlukannya.), Maqālah Samt al-Qiblah bi al-Hisāb (Makalah 


\section{Asas Ontologi dalam Penyelidikan Alam Tabii}

Ibn al-Haytham tidak secara khas membincangkan masalah ontologi, tetapi pandangannya yang berkaitan dengan asas ontologi dalam ilmu pengetahuan dapat diketahui melalui beberapa pandangannya secara tersirat. Dalam $M T H H$ dan juga pelbagai karya lainnya, Ibn al-Haytham menyatakan bahawa matlamat dari mengetahui dan mempelajari alhikmah adalah untuk mengetahui pelbagai wujud yang ada:

"Manusia akan sempurna makna
kemanusiaannya dengan mencari
kesempurnaannya sebagai manusia, dan hal
tersebut dengan memperoleh apa yang
diinginkan oleh jiwa rasionalnya (al-nafs al-
nātiqah), iaitu kebahagiaan yang telah kami
sebutkan iaitu keterbebasan daripada yang
selain kepedihan, yang tidak lain daripada al-
hikmah, buah darinya adalah mengetahui
hakikat segala yang ada [al-mawjüdât] dan
dasar-dasarnya, alasan-alasannya, dan sebab-
sebabnya."39

Pernyataan Ibn al-Haytham tersebut menunjukkan bahawa beliau mengiktiraf bukan sahaja adanya kepelbagaian dalam wujud tetapi juga mengithbatkan adanya darjah dalam pelbagai wujud itu, dan wujud Tuhan merupakan wujud yang paling tinggi. Hal ini disebabkan kerana beliau meletakkan bahagian metafizik menjadi pengetahuan falsafah tertinggi. Ini menunjukkan bahawa

tentang Arah Kiblat dengan Menggunakan Perhitungan Matematik). Juga beberapa karyanya yang ditujukan sebagai panduan amaliah yang dapat digunakan masyarakat seperti: Qawl fi Istikhrāj A'midah al-Jibāl (Perbincangan tentang Penentuan Ketinggian dari Gunung), Maqālah fì Khuțùt al-Sā'ah (Makalah tentang Jam Matahari), Maqālah fí Ijārāt al-hufūr wa al-Abniyyah yajmi 'ah al-Ashkāl alHandasiyyah (Makalah Tentang Penggalian dan Pembinaan dalam Seluruh Bentuk Geometrinya), dan lain-lain.

${ }^{39} \mathrm{MTHH}(31)$. 
baginya wujud metafizik, seperti Tuhan, adalah yang tertinggi dan paling sempurna:

"Dan melalui mantik akan sampai kepada ilmu tentang alam (tabi $\mathfrak{\imath})$ iaitu al-Hikmah, dasardasarnya, alasan-alasannya, sebab-sebabnya sampai pada ilmu tentang metafizik (ilähiyyah) yang dengan hal tersebut kemudian ia memahami al-hikmah Allāh Ta'àlā, berzikir padaNya dalam keteraturan langit dan bumi dan yang ada di antaranya maka semestinya dengan hal itu ia mengisbatkan (keyakinan, pent.) terhadap Sang Pencipta (al-Bārī), Tuhan yang disembah (al-Ilāh), yang Maha Tinggi (Ta 'àla), Maha Bijaksana (hakìm), Maha Kuasa (Qādir), dan Maha Mengetahui (Khabìr)." ${ }^{40}$

Dari pernyataan Ibn al-Haytham di atas, dapat pula diketahui bahawa alam adalah sebuah perlambangan dan perwujudan atas keagungan dan kebesaran Allāh. Bagi Ibn al-Haytham alam semesta merupakan 'alam besar' yang dikenal dengan konsep mikrokosmos atau 'ālam kullì dan diri manusia merupakan 'alam kecil' atau mikrokosmos atau ' 'âlam juz' $\vec{\imath}$. Hal ini tercermin dalam salah satu karyanya bertajuk Makalah tentang Keserupaan Alam Kecil (Mikrokosmos) iaitu Manusia dengan Alam Besar (Makrokosmos) (Maqālah fì Mushākalah al- 'Ālam al-Juz'̄̄ wa huwa al-Insān li al- 'Ālam al-Kullī).

Karya ini meskipun tidak dapat ditemukan hingga saat ini, ${ }^{41}$ memberi petunjuk bahawa Ibn al-Haytham telah mengiktiraf konsep mikrokosmos dan makrokosmos yang sememangnya sangat dikenal dalam tradisi keilmuan Islām, yang memandang bahawa ada tiga kawasan yang dapat dibezakan iaitu kawasan metafizik, kosmos, dan jiwa manusia yang masing-masing bersesuaian dengan Tuhan,

\footnotetext{
${ }^{40}$ MTHH (45).

${ }^{41}$ Lihat dalam senarai karya Ibn al-Haytham di dalam 'Uyūn.
} 
dan ciptaanNya iaitu alam semesta atau makrokosmos, dan manusia atau mikrokosmos. ${ }^{42}$ Konsep mikrokosmosmakrokosmos tidak lain adalah kesedaran bahawa manusia merupakan perwujudan ringkas (epitome) daripada keseluruhan kosmos yang diciptakan Tuhan. ${ }^{43}$

Oleh itu, bagi Ibn al-Haytham, kajian terhadap alam semesta merupakan bentuk dhikr kepada Penciptanya, ia menyatakan:

"...dengan hal tersebut kemudian ia memahami al-Hikmah Allāh Ta'ālā, berzikir padaNya dalam keteraturan langit dan bumi dan yang ada di antaranya maka semestinya dengan hal itu ia mengukuhkan (keyakinan, -pent.) Sang Pencipta (al-Bāri), Tuhan yang disembah (alIlāh), yang Maha Tinggi (Ta'ālā), Maha Bijaksana (al-Hakim), Maha Kuasa (al-Qādir), dan Maha Mengetahui (al-Khabīr)." ${ }^{44}$

Dalam pandangan Islam, konsep makrokosmosmikrokosmos ini pada dasarnya merupakan sebuah tayangan daripada pelbagai ayat dalam al-Qur'an yang telah menjelaskan bahawa alam semesta iaitu makrokosmos dan diri manusia iaitu mikrokosmos adalah tanda daripada Sang Pencipta. Misalnya sebuah ayat dalam al-Qur'an:

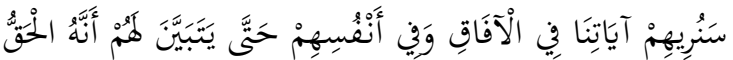

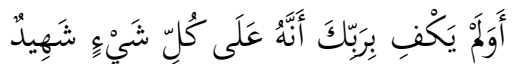

Terjemahan: Kami akan memperlihatkan kepada mereka tanda-tanda (kekuasaan) Kami di segala wilayah bumi dan pada diri mereka

2 Titus Burckhardt, Introduction to Sufi Doctrine (Bloomington, Indiana: World Wisdom, 2008), 26.

${ }^{43}$ Syed Muhammad Naquib al-Attas, Prolegomena to the Metaphysics of Islam (Kuala Lumpur: ISTAC, 1995; repr. Kuala Lumpur, ISTAC, 2001), 58.

${ }^{44}$ MTHH (45). 
sendiri, hingga jelas bagi mereka bahawa $\mathrm{Al}$ Quran itu adalah benar. Tiadakah cukup bahawa Sesungguhnya Tuhanmu menjadi saksi atas segala sesuatu?"

\section{Al-Fușșilat 41:53}

Hadith Nabi SAW menyatakan bahawa manusia diciptakan menurut gambaran Tuhan sendiri yang bermaksud:

"Allāh menciptakan Ādam sesuai dengan gambaran diriNya." 45

Konsep ini tidaklah asing bahkan merupakan tayangan yang bersumberkan pada al-Qur' an itu sendiri, iaitu bahawa kajian terhadap alam semesta sebagai $\bar{a} y \bar{a} t$ mesti sampai pada kesedaran dan keyakinan kepada sang Pencipta, yang merupakan ciri daripada seorang $u l \bar{u}$ al-albāb sebagaimana telah dihuraikan sebelum ini.

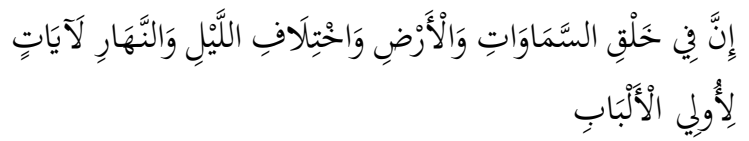

Terjemahan: Sesungguhnya dalam penciptaan langit dan bumi, dan silih bergantinya malam dan siang terdapat tanda-tanda bagi $\bar{u} l \bar{u}$ alalbāb.

Ali 'Imrān 3:190

Hubungan antara $\bar{u} l u$ al-albāb dan al-hikmah juga dapat dilihat daripada al-Qur'an sendiri yang mengaitkan orang yang telah diberikan hikmah dengan mereka yang mampu mengambil pelajaran:

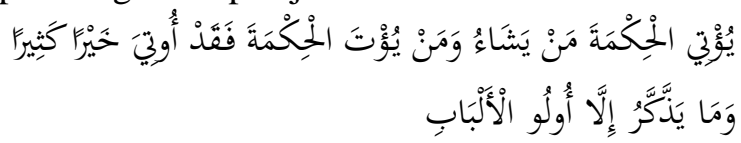

Terjemahan: Allāh menganugerahkan alhikmah kepada siapa yang dikehendaki-Nya.

45 Șah̄inh Muslim, Buku 32 Hadīth nombor 6325. 
Dan barangsiapa yang dianugerahi al-hikmah, ia benar-benar telah dianugerahi karunia yang banyak. Dan hanya orang-orang yang berakallah yang dapat mengambil pelajaran (ùlū al-albāb).

Al-Baqarah 2:269

Ini menunjukkan bahawa pernyataan Ibn al-Haytham yang menghubungkan konsep al-hikmah dengan berzikir kepada Tuhan yang menciptakan alam semesta, Sang

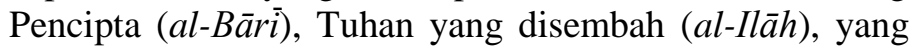
Maha Tinggi ( Ta $^{\prime} \bar{a} l \bar{a}$ ), Maha Bijaksana (al-Hakim), Maha Kuasa (al-Qādir), dan Maha Mengetahui (al-Khabir); dan kemudian mengambil pelajaran daripadanya dalam bentuk mengukuhkan keyakinan kepadaNya, iaitu $\bar{u} l \bar{u}$ al-albāb, tidak lain daripada konsep yang memiliki landasan khas di dalam al-Qur'an, dan tidak dikenal dalam tradisi falsafah Yunani.

Pandangan Ibn al-Haytham tentang makrokosmosmikrokosmos ini juga dapat ditemukan dalam pemikiran pelbagai sarjana Islām seperti Abū Rayḥan al-Bīrūn̄̄ (362/973-442/1051). ${ }^{46}$ Juga sebenarnya telah mendahului beberapa sarjana lainnya yang lebih dikenal seperti Ibn Sīnā (370/980-428/1037), ${ }^{47}$ Abū Hamīd al-Ghazālī (w. 505/1111), Abū Bakr Muḥammad ibn al-'Arabī al-Ḥātimī al-Ṭā' ${ }^{\top} \quad(560 / 1165-595 / 1196),{ }^{48}$ Jalāl al-Dīn Rūmī

46 Seyyed Hossein Nasr, An Introduction to Islamic Cosmological Doctrines (Great Britain: Thames and Hudson, 1978), 149.

47 Seyyed Hossein Nasr, Three Muslim Sages (Delmar NY: Caravan Books, 1976), 32.

${ }^{48}$ William C. Chittick, "Microcosm, Macrocosm, and Perfect Man in the View of Ibn al-'Arabī”, dalam Islamic Culture vol. 63I (January-April 1989), 1-4 passim. 
(604/1207-672/1273) ${ }^{49}$ dan 'Abd al-Karīm Quṭb al-Dīn ibn Ibrāhīm al-Jīili (767/1365-812/1409). ${ }^{50}$

Al-Ghazālī sentiasa menghubung-kaitkan perbahasan konsep makrokosmos-mikrokosmos dengan tema Imago $D e i,{ }^{51}$ khasnya berdasarkan hadīth Nabi SAW tentang penciptaan manusia yang menyerupai bentuk Tuhan, ${ }^{52}$ dalam pengertian bahawa keserupaan tersebut terletak pada kekuasaan Tuhan terhadap alam semesta atau makrokosmos dengan 'kekuasaan' manusia terhadap seluruh fakulti dalam dirinya atau mikrokosmos. ${ }^{53}$ Dengan demikian terdapat kesesuaian (correspondence) antara kekuasaan Allāh ke atas alam semesta dengan kekuasaan manusia terhadap seluruh fakulti yang ada padanya. Di dalam Kimiya $\bar{a}^{\prime}$ al-Sa'ādah, al-Ghazālī menyatakan konsepnya tentang 'ālam șaghìr:

"Kerana itu, sangat pantas jika manusia disebut 'ālam al-ṣaghìr (mikrokosmos). Struktur jasadnya mesti dipelajari, bukan hanya oleh orang yang ingin menjadi doktor, melainkan juga oleh orang yang ingin mencapai pengetahuan lebih dalam tentang Tuhan." ${ }^{4}$

${ }^{49}$ Éric Geoffroy, Introduction to Sufism: The Inner Path of Islam, terj. Roger Gaetani (Bloomington, Indiana: World Wisdom, 2010), 90.

50 'Abd al-Karīm Quṭb al-Dīn ibn Ibrāhīm al-Jīlī, "Al-Kahf wa alRaqīm"; Nicholas Lo Polito, "Abd al-Karīm al-Jīlī: Tawhīè, Transcendence and Immanence" (tesis Ph.D, University of Birmingham, 2010), 219.

${ }^{51}$ Masataka Takeshita, Ibn 'Arabi's Theory of the Perfect Man and Its Place in the History of Islamic Thought, terj. Harir Muzakki, Insan Kamil Pandangan Ibnu 'Arabi: Sebuah Disertasi (Surabaya: Risalah Gusti, 2005), 108.

52 Sahīh Muslim Book 32 Hadīth Number 6325.

${ }^{53}$ Masataka Takeshita, Ibn 'Arabi's Theory of the Perfect Man, 109; rujuk juga: Abū Hamīd al-Ghazālī, Kimiyā al-Sa'ādah, terj. Dedi Slamet Riyadi \& Fauzi Bahreisy, Kimiyā al-Sa'ādah Kimia Ruhani untuk Kebahagiaan Abadi (Jakarta: Penerbit Zaman, 2001), 24.

${ }^{54}$ Abū Ḥamīd al-Ghazālī, Kimiyā al-Sa àdah, 24. 


\section{Asas Epistemologi: Saluran Ilmu Pengetahuan}

Dalam segi epistemologi khasnya berkaitan dengan sumber-sumber dan saluran-saluran ilmu pengetahuan, Ibn al-Haytham tidak mempertentangkan penggunaan saluran akal (rasional) dengan penggunaan deria manusia (empirikal), kerana bagi Ibn al-Haytham masing-masing saluran ilmu pengetahuan tersebut memiliki kekurangan, keterbatasan dan kelebihannya yang saling memperlengkapi. Ibn al-Haytham memberikan permisalan bahawa mata manusia tidak dapat melihat biji mata seekor nyamuk meski ia mengetahui keberadaannya:

"Kerana biji mata seekor nyamuk dan begitu juga benda-benda yang sangat kecil lainnya tiada dapat dicerap oleh mata, meskipun mereka adalah benda-benda yang mawjüd.'

Meskipun demikian, Ibn al-Haytham meyakini meski indera manusia diliputi keterbatasan ia adalah alat pembuktian yang diiktiraf dan dapat digunakan dalam melakukan penyelidikan alam tabii. Beliau menyatakan:

$$
\begin{aligned}
& \text { وما نحن مع جميع ذلك برآ مما هو في طبيعة الإنسان من } \\
& \text { كدر البشرية ولكنا نجتهد بقدر ما هو لنا من القوة الإنسانية } \\
& \text { ومن الله نستمد المعونة في جميع الأمور }
\end{aligned}
$$

Terjemahan: Dan tiadalah kita berserta seluruh hal tersebut terbebas daripada tabiat manusia (al-insān) iaitu keruhnya (keterbatasan, -pent.) manusia (al-bashariyah) tetapi kita harus bersungguh-sungguh dengan kekuatan yang ada pada kita iaitu daya kemanusiaan (al-quwwah al-insāniyyah) dan kepada Allāh kita menyandarkan pertolongan dalam seluruh urusan. ${ }^{56}$

${ }^{55} K M, 66\{9\}$.

${ }^{56} K M, 62\{6\}$. 
Di sisi lain, bagi Ibn al-Haytham akal turut memiliki keterbatasan:

"Setiap garis yang terkhayalkan (mutakhayyal) dan terindera (mahsūs) haruslah terbatas (muntāhiyan), kerana apa yang tiada terbatas tiada dapat dicerap dengan deria ataupun dikhayalkan." ${ }^{57}$

"Tiada mungkin untuk mengkhayalkan sesuatu yang tiada terbatas, kerana setiap segala sesuatu yang boleh dikhayalkan adalah terbatas." ${ }^{58}$

Selain indera dan akal, Ibn al-Haytham juga mengiktiraf berita yang benar dan autoriti sebagai sumber kebenaran. Meskipun demikian ia membezakan sikap terhadap berita yang berasal dari sumber-sumber kenabian, seperti wahyu dan hadīth Nabi SAW, dengan autoriti keilmuan dalam ilmu-ilmu akliah. Beliau misalnya menyatakan:

"Maka pencari kebenaran bukanlah ia yang menyerang karya-karya orang-orang terdahulu, dan bukan juga yang menerima begitu sahaja salinan karya mereka dengan baik sangka terhadap mereka, tetapi pencari kebenaran iaitu yang curiga terhadap sangkaannya terhadap mereka, dan bergantung terhadap apa-apa yang ia fahami dari mereka, dan ia adalah pengikut hujah dan bukti-bukti. ${ }^{59}$

Ia menyatakan juga dalam menyingkap pernyataanpernyataan ilmiah, seseorang tidak dapat meragukannya kecuali ada alasan untuk meragukannya:

${ }^{57}$ Ibn al-Haytham, "Sharḥ Muṣādarāt Kitāb Uqlīdis fī al-Uṣūl”, ed., terj., Barbara Hooper Sude, 6 \{Barbara Hooper Sude, "Ibn al-Haytham's Commentary on the Premiss of Euclid's Elements Book I-IV" (tesis Ph.D., Princeton University, 1974), 25.

${ }^{58}$ Ibid., $26\{49\}$.

${ }^{59} \mathrm{Ibn}$ al-Haytham, al-Shukūk 'alā Bațlamyūs, 3-4. 
"Namun tiadalah dibenarkan untuk meragukan apa pun kecuali terdapat alasan yang menghadirkan adanya keraguan tersebut." 60

Untuk khabar yang berasal dari sumber-sumber kenabian, bagi Ibn al-Haytham, maka ia mesti diikuti (taqlìd):

"Namun hanya peniruan murni (taqlìd); seperti itulah cara para ahli hadìth mempercayai para Nabī, șalawātullāh 'alayhim [italik dari penulis]. Tetapi itu bukan cara ahli matematik mempercayai para ahli dalam ilmu-ilmu burhani. $"$ "61

Oleh itu, jelaslah bahawa Ibn al-Haytham mengiktiraf pelbagai sumber dan kaedah untuk meraih kebenaran yang masing-masing mesti digunakan sesuai dengan tempatnya. Bahkan, bagi Ibn al-Haytham seorang yang ahli dalam bidang matematik sahaja tidak boleh menjelaskan aspekaspek yang lebih mendalam dan filosofis apabila dia tidak memiliki kapasiti tersebut. Jika dia memiliki kapasiti lebih dari seorang ahli matematik misalnya ia juga seorang ahli Kalām, maka ia boleh menjelaskan aspek falsafah. Hal ini dapat difahami dari pernyataannya berikut:

${ }^{60} K M, 158\{81\}$.

${ }^{61}$ Ibn al-Haytham, "F̄̄ ḥāl Shukūk ḥarakat al-Iltifāf", St. Petersburg, MS B1030/1 fol. 19v:

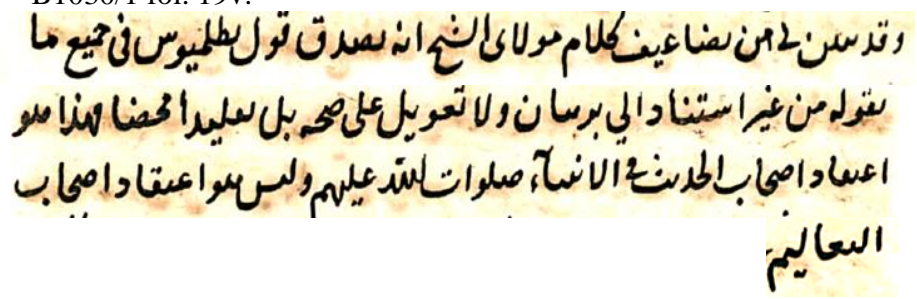

cf. bahagian manuskrip disunting dan diterjemahkan ke dalam bahasa Inggeris oleh Roshdi Rashed dalam "The Celestial Kinematics of Ibn al-Haytham," Arabic Sciences and Philosophy, 17 (2007), 11. 


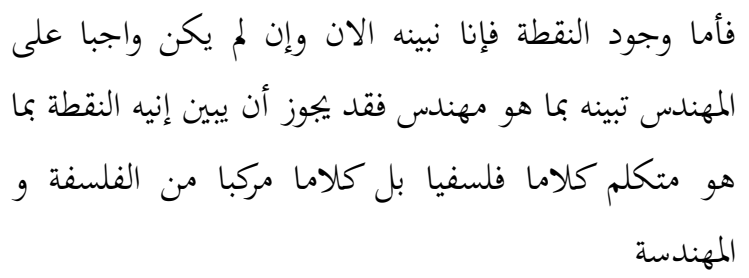

Terjemahan: Adapun wujud suatu titik maka kami akan menjelaskannya sekarang. Namun bukan suatu kewajiban bagi seorang ahli geometri, sebagai seorang ahli geometri, untuk menjelaskan hakikat dari titik kecuali ia seorang ahli Kalām falsafi bahkan seorang ahli Kalām yang juga sekaligus ahli falsafah dan geometri. ${ }^{62}$

Kemudian Ibn al-Haytham menyatakan bahawa terdapat perkara-perkara di mana para ahli falsafah dalam hal ini ahli sains alam tabii lebih berhak dari ahli matematik:

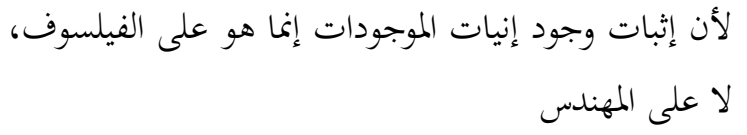

Terjemahan: ...kerana pembuktian adanya hakikat dari benda-benda sesungguhnya adalah pada ahli falsafah, bukan pada ahli matematik. ${ }^{63}$

Di sini sangat jelas bahawa bagi Ibn al-Haytham, kaedah mesti digunakan sesuai dengan setiap bidang keilmuan. Oleh itu, sekurang-kurangnya terdapat tiga sumber dan kaedah pengetahuan yang secara jelas dinyatakan oleh Ibn al-Haytham, iaitu:

62 'Ammār, "Kitāb Thamarah al-Hikmah li Ibn al-Haytham Dirāsah wa Taḥqīq," 271. Cf. Ibn al-Haytham, Kitāb Fī Hall Shukūk Kitāb Uqlīdis F̄̄ al-Ușūl Wa Sharh Ma ānīhi (facsimile edition) (Frankfurt: Institut for the History of Arabic-Islamic Science at the Johann Wolfgang Goethe University, 1985), 5.

${ }^{63}$ Ibid., 6. 
i. rasional;

ii. empiris;

iii. autoriti: autoriti keagamaan dan autoriti keilmuan.

Hal ini menunjukkan bahawa para ahli sains alam tabii seperti Ibn al-Haytham dan al-Bīrūnī, ${ }^{64}$ secara khasnya dan amnya para sarjana Islam di masa lalu telah menggunakan kerangka-kerja keilmuan Islam sebagaimana yang telah disebutkan sebelum ini bahawa Islam menerima pelbagai sumber dan jalan ilmu pengetahuan:

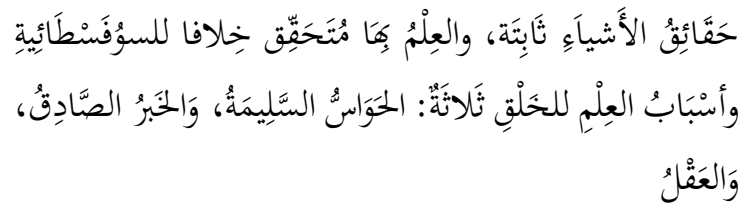

Terjemahan: Semua hakikat segala perkara adalah sabit adanya dan pengetahuan akan ia sebenarnya, bersalahan dengan kaum sūfastāìyyah. Maka segala perkara yang menghasilkan 'ilmu bagi makhluqāt itu tiga perkara: pancaindera yang lima, khabar șädiq (ya 'nī berita yang benar); ketiga 'aqal." 65

\section{Kerangka-Kerja (Framework) Islāmik dalam Penyelidikan Ilmiah}

Dalam melakukan penyelidikan terhadap alam tabii, Ibn alHaytham telah menggunakan pandangan alam Islam. Bagi Ibn al-Haytham, alam semesta sebagai objek bagi penyelidikan sains tabii sememangnya adalah ciptaan Allah dari ketiadaan, tetapi juga ia dibentuk, dirancang, dan dipelihara, serta memiliki matlamat-matlamat tertentu dalam penciptaanNya, iaitu bahawa alam merupakan

64 Seyyed Hossein Nasr, An Introduction to Islamic Cosmological Doctrines, 125.

${ }^{65}$ Najm al-Dīn al-Nasafī, 'Aqā'id al-Nasafì, terj. ed. Syed Muhammad Naquib al-Attas, The Oldest Known Malay Manuscript: A $16^{\text {th }}$ Century Malay Translation of the 'Aqāid of al-Nasafi (Kuala Lumpur: Department of Publication University of Malaya, 1988), 65-66. 
perwujudan daripada kekuasaan dan kemahakuasaan Penciptanya. Inilah kerangka metafizik Ibn al-Haytham dalam penyelidikan ilmiahnya sebagaimana beliau nyatakan:

$$
\begin{aligned}
& \text { وتخصص البصر بهذه الخاصة هو أحد المعاني التي تظهر منها } \\
& \text { حكمة الصانع جّلت عظمته ولطف صنيعه ويظهر منه حسن } \\
& \text { تأتي الطبيعة وتلطفها في فيئة آلات البصر الهيئة التي بها يتم } \\
& \text { الإحساس وبها تتميز له المبصرات. }
\end{aligned}
$$

Istilah șāni yang digunakan dalam pernyataan Ibn alHaytham di atas tidak lain sememangnya merupakan konsep yang bersumber dari al-Qur' an. Di dalam al-Qur'an salah satu nama bagi Tuhan yang digunakan berkaitan

\footnotetext{
${ }^{66} K M, 187-188$ \{103\}; juga rujuk:

فهذه المعاني التي ذكرناها هي منافع آلات البصر وهي لطائف تتبين منها حكمة الصانع تعلى ورأفنه وبديع صنعته وحسن تأتي الطبيعة ولطيف آثارها.
}

"Makna-makna ini yang telah kami sebutkan ialah kegunaan daripada alat penglihatan dan ia adalah sesuatu yang sangat halus yang membuktikan kebijaksanaan Maha Pembentuk (hikmah al-șāni') Yang Maha Tinggi dan ketinggian serta keluarbiasaan karyanya dan sebaikbaik tabiatnya dan sehalus-halus dalam pengerjaannya (KM, 189 $\{104\})^{\prime \prime}$ 
dengan proses penciptaan alam adalah al-șāni . Ia berasal daripada akar kata $s$ - $n$-', yang bermakna 'menghasilkan', 'membentuk' dan 'membina' (manufactured, fabricated, constructed). ${ }^{67}$

Penggunaan kata $s-n$ - $^{\prime}$ di dalam al-Qur'an sekurangnya ada dalam 11 turunan kata, ${ }^{68}$ tiga di antaranya berkaitan dengan perbuatan Tuhan, iaitu: șun ' $u$ Allāh di dalam sūrah al-Naml 27:88, sūrah Țāhā 20:39, dan 41 terdapat ayat yang mengandungi istilah "wa'ștana'tuka li nafs $\vec{\imath}$ '. Menurut al-Raghīb al-Așfahān̄i, isțanā'u bermakna meletakkan sesuatu lebih baik daripada lazimnya (almubālaghatu fì ișlāh al-shay'), oleh itu "iștana'tu" diterjemahkan sebagai 'memilih'. ${ }^{69}$ Dengan demikian, istilah yang telah digunakan Ibn al-Haytham ini mengandungi suatu konsep bahawa alam semesta telah dirancang, diwujudkan oleh Allah SWT daripada ketiadaan dalam bentuk terbaiknya dalam ukuran ( $q a d r)$ tertentu.

Menurut al-Ghazālī, al-Ṣāni menyiratkan bahawa alam diwujudkan dari ketiadaan, kerana ia adalah bermula $(s a b a b)$, dan setiap yang bermula ( $s a b a b)$ adalah baharu, dan setiap yang baharu memiliki penyebab (al-Musabbib) atau disebut juga al-Ṣāni.$^{70}$ Di sini al-Ghazālī menyamakan sifat Allah sebagai al-Musabbib dengan alȘāni dalam hal bahawa keduanya mengandungi makna menciptakan dari ketiadaan. Bagi Ibn al-Haytham penyelidikan terhadap alam tabii khasnya, merupakan kegiatan yang ditujukan untuk mengingati Pencipta dan

${ }^{67}$ Edward Willian Lane, Arabic-English Lexicon, vol. 4 (8 vol.) (Beirut: Librairie du Liban, 1968), 456.

${ }^{68}$ Al-Rāghib al-Așfahān̄̄, Mu 'jam Mufradāt Alfāz al-Qur'ān (Beirut: Dār al-Kutub al-'Ilmiyyah, 2008), 321.

${ }^{69}$ Ibid.

70 Abū Ḥāmid al-Ghazālī, al-Iqtiṣād fì al-I tiquād, ed. Inșāf Ramaḍān (Beirut: Dār al-Qutaybah ,2003 ), 35; rujuk juga: Hamid Fahmy Zarkasyi, al-Ghazālì Concept of Causality (Kuala Lumpur: IIUM Press, 2010), 101. 
memperkukuh keyakinan terhadap Tuhan dengan segala sifat-sifat dan perbuatanNya. Beliau menyatakan:

"Dan melalui mantik (mantiq) akan sampai kepada ilmu tentang alam (tabi $i$ ) iaitu alHikmah, dasar-dasarnya, alasan-alasannya, sebab-sebabnya sampai pada ilmu tentang metafizik (ilāhiyyah) yang dengan hal tersebut kemudian ia memahami al-Hikmah Allāh Ta'àlă, berzikir padaNya dalam keteraturan langit dan bumi dan yang ada di antaranya maka semestinya dengan hal itu ia mengukuhkan (keyakinan, -pent.) Sang Pencipta (al-Bārī), Tuhan yang disembah (al-Ilāh), yang Maha Tinggi (Ta'āla), Maha Bijaksana (hakìm), Maha Kuasa (Qädir), dan Maha Mengetahui (Khabir).",71

Konsep Ibn al-Haytham tentang alam dan Tuhan jelas berbeza dengan pandangan para ahli falsafah Yunani. Tuhan dalam pandangan Ibn al-Haytham bukanlah sekadar prime mover, akan tetapi Dia juga Tuhan Pencipta (alBārí), Tuhan yang mesti disembah (al-Ilāh), Tuhan Pembentuk (al-Șāni ${ }^{\prime}$ ), Tuhan yang Maha Mengetahui (alKhabìr) dan Tuhan yang Maha Kuasa (al-Qadīr) atas ciptaan-Nya, juga Tuhan yang aktif Mendengar permintaan manusia. $^{72}$

Bagi Ibn al-Haytham Tuhan adalah juga pelaku awal (al-fāil al-awwal), yang awal permulaan (mabda'almabādi ), yang pertama dari segala permulaan (awwal al-

${ }^{71}$ MTHH (45).

${ }^{72}$ Sebagaimana sering Ibn al-Haytham nyatakan dalam karya-karyanya dalam bentuk meminta pertolongan kepada Tuhan dalam melakukan kegiatan ilmiahnya, e.g. "terlepas dari semua ini, kita tiadalah terbebas dari kelemahan dari tabiat seorang manusia. Tetapi kita haruslah berusaha dengan seluruh daya yang kita miliki, dan kepada Allah jua kita bermohon pertolongan dalam setiap perkara." ( $K M\{62\} 6)$. 
$\left.a w \bar{a}{ }^{\prime} i l\right) ;{ }^{73}$ dan yang juga penting iaitu bahawa Tuhan dalam pandangan Ibn al-Haytham memiliki nama sebenar ( proper name) yang bersumberkan kepada wahyu, tidak sebagaimana hasil dugaan, perenungan, atau spekulasi ahli falsafah Yunani. Pandangan Ibn al-Haytham tentang Tuhan dan alam tersebut jelas bercanggah dengan konsep para ahli falsafah termasuklah pandangan Aristotle yang sebenarnya Ibn al-Haytham ikuti dalam beberapa segi.

Bagi Aristotle khasnya, prime mover hanyalah penggerak awal, Dia bukan Tuhan Pencipta alam semesta yang mengatur dan mentadbir alam semesta, kerana alam semesta menurut Aristotle tidak bermula, ${ }^{74}$ yang sulit dirundingkan dengan pandangan Islām yang memandang alam semesta diciptakan dari ketiadaan (creatio ex nihilo). Tuhan dalam pemahaman Aristotle adalah Tuhan yang tidak mendengar permintaan manusia, pasif iaitu tiada memikirkan tentang makhlukNya dan hanya memikirkan dirinya sendiri, dan tidak memiliki hubungan timbalbalik $^{75}$, seperti memberi kurnia ataupun memberi hukuman, ${ }^{76}$ dan oleh itu tidak memiliki kegunaan

\footnotetext{
${ }^{73}$ МTHH (30).

74 W.D. Ross, "Introduction", dalam Aristotle Metaphysics vol. I, (London: Oxford University Press, 1975), cliii; rujuk juga: Janet Martin Soskice, Philosophers and God, ed. John Cornwell dan Michael McGhee (New York: Continuum, 2009), 82; Richard Sorabji, "Infinite Power Impressed: The Transformation of Aristotle's Physics and Theology" dalam Aristotle Transformed the Ancient Commentators and Their Influence, ed. Richard Sorabji (Itacha NY: Cornell University Press, 1990), 181.

75 Etienne Gilson, God and Philosophy (USA: New Haven Yale University Press, 1944), 33; rujuk juga: Janet Martin Soskice, Philosophers and God, 84.

${ }^{76}$ Oliver Leaman, History of Islamic Philosophy, ed. Seyyed Hossein Nasr dan Oliver Leaman (London: Routledge Taylor \& Francis Group, 1996), 1358; Wan Mohd Nor Wan Daud, Budaya Ilmu Satu Penjelasan (Singapura: Pustaka Nasional Ltd., 2007; repr. Kuala Lumpur, Dewan Bahasa dan Pustaka, 1991), 15.
} 
keagamaan dan bahkan Aristotle sendiri telah mengabaikan agama. $^{77}$

\section{Kesimpulan}

Dari huraian di atas, dapatlah disimpulkan bahawa falsafah sains Ibn al-Haytham memiliki kerangka pandangan alam Islam. Sains alam tabii dalam pandangan Ibn al-Haytham tidak dapat diasingkan dari keseluruhan bangunan alhikmah yang memiliki matlamat menjadi manusia yang sempurna (al-insān al-tāmm) iaitu manusia yang telah berusaha menurut kadar kemanusiaannya meniru perbuatan-perbuatan Tuhan. Selain itu, alam tabii juga dikaji untuk matlamat-matlamat lain iaitu untuk kemanfaatan dan kebaikan umat manusia dalam hal keperluan keduniaan ataupun keperluan-keperluan peribadatan-keagamaan.

Dalam segi-segi epistemologi, beliau mengiktiraf tiga saluran kebenaran meliputi rasional, empirikal dan autoriti, iaitu autoriti keagamaan dan autoriti keilmuan secara umum. Bagi Ibn al-Haytham setiap sumber pengetahuan di atas mesti digunakan secara tepat sesuai dengan wilayahnya (subject matter) masing-masing. Ibn alHaytham mengiktiraf kepelbagaian wujud dan darjah dari pelbagai wujud tersebut, dan darjah tertinggi adalah Allāh SWT. Dari huraian ini juga tampak jelas konsep ketuhanan dan alam dalam pandangan Ibn al-Haytham yang merupakan tayangan dari pandangan alam Islām.

\section{Rujukan}

Abū Farrāj ibn Harūn ibn al-'Ibrī. Tārikh Mukhtașar al-

Duwal, ed. Anțūn Șālhān̄ī. Beirut: al-Maṭba'ah alKātūlīkiyyah, 1958.

77 Etienne Gilson, God and Philosophy, 34; rujuk juga: Karen Armstrong, History of God The 4,000 Year Quest of Judaism, Christianity and Islam (London: Vintage, 1999), 50-1. 
Abū Rīdah, Muḥammad 'Abd al-Hādī. "Preface.” Dalam Maqālah 'an Thamarah al-Hikmah. Kaherah: alMaktabāt al-Miṣriyyah bi al-Qāhirah, 1991.

Armstrong, Karen. History of God The 4,000 Year Quest of Judaism, Christianity and Islam. London: Vintage, 1999.

Al-Așfahān̄̄, Al-Rāghib. Mu jam Mufradāt Alfāz alQur'ān. Beirut: Dār al-Kutub al-' Ilmiyyah, 2008.

Al-Attas, Syed Muhammad Naquib. Prolegomena to The Metaphysics Of Islam. Kuala Lumpur: ISTAC, 1995; repr. Kuala Lumpur, ISTAC, 2001.

Al-Bayhaq̄ī Zahīr al-Dīn. Tatimmah al-Ṣiwān al-Hikmah. Beirut: Dār al-Fikr al-Lubnān̄̄, 1994.

Brockelmann, Carl. Geschichte Der Arabischen Litteratur Vol. I. Leiden: E.J. Brill, 1943.

Burckhardt, Titus. Introduction to Sufi Doctrine. Bloomington, Indiana: World Wisdom, 2008.

Chittick, William C. "Microcosm, Macrocosm and Perfect Man in the View of Ibn al-' Arabī', Islamic Culture vol. 63I, 1989.

Corbin, Henry. History of Islamic Philosophy, terj. Liadain Serrard dan Philip Sherrard. London: Kegan Paul International, 1993.

Dallal, Ahmad S. "Ibn al-Haytham's Universal Soultion for Finding the Direction of the Qibla by Calculation," Arabic Sciences and Philosophy, vol. 5, 1995.

El-Bizri, Nader, "A Philosophical Perspective on Alhazen's Optics," Arabic Sciences and Philosophy, vol. 15, 2005. Al-Fārisī, Kamāl al-Dīn. Kitāb Tanqih al-Manāzir li Dhawi al-Abșār wa al-Bașā'ir vol. 2. Hyderabad: Dā'irah alMa`ārif al-'Uthmānīyah, 1348 A.H.

Geoffroy, Éric. Introduction to Sufism: The Inner Path of Islam, terj. Roger Gaetani. Bloomington, Indiana: World Wisdom, 2010.

Al-Ghazālī, Abū Ḥāmid. Al-Iqtișād fì al-I'tiqād, ed. Inșāf Ramaḍān. Beirut: Dār al-Qutaybah, 2003. 
Al-Ghazālī, Abū Hāāmid. Kimiyā al-Sa'ādah (Kimiyā alSa 'ädah Kimia Ruhani untuk Kebahagiaan Abadi), terj. Dedi Slamet Riyadi \& Fauzi Bahreisy. Jakarta: Penerbit Zaman, 2001.

Gilson, Etienne. God and Philosophy. USA: New Haven Yale University Press, 1944.

Hamid Fahmy Zarkasyi. Al-Ghazālī Concept of Causality. Kuala Lumpur: IIUM Press, 2010.

Ibn Abi Usaybi 'ah. 'Uyūn al-Anbā' fì Tabaqāt al-Ațibbā'. Beirut: Dar al-Kutūb al-'Ilmiyyah, 1998.

Ibn al-Haytham. "F̄̄ hāāl Shukūk Harakat al-Iltifāf", MS B1030/1 fol. 19v, St. Petersburg.

Ibn al-Haytham. "Kitāb Thamarah al-Hikmah li Ibn alHaytham Dirāsah wa Taḥqīq." Dalam Majallah Majma al-Lughah al-'Arabiyah bi Dimashq April 73 No. 2. Damsyik: Majma' al-Lughah al-'Arabiyah bi Dimashq, 1998.

Ibn al-Haytham. "Risālah fī al-Daw'." Dalam Majmū' alRasā'il li al-Hasan ibn al-Hasan Ibn al Haytham. Hyderabad: Dā'irah al-Ma'ārif al-'Uthmānīyah, 1938; repr., Frankfurt: Institute for the History of ArabicIslamic Science at the Johann Wolfgang Goethe University, 1998.

Ibn al-Haytham. "Risālah fī Khawāṣṣ al-Muthallath min Jihat al- 'Amūd." Dalam Majmū 'al-Rasā'il li al-Hasan ibn al-Hasan Ibn al-Haytham. Hyderabad: Dā' irah alMa'ārif al-'Uthmānīyah, 1938.

Ibn al-Haytham. Al-Shukūk 'alā Bațlamyūs li al-Hasan ibn al-Haytham, ed. A.I. Sabra and N. Shehaby. Kaherah: Maṭba'ah Dār al-Kutūb, 1971.

Ibn al-Haytham. Kitāb al-Manāzir li al-Hasan Ibn alHaytham, ed. A.I. Sabra. Kuwait: The National Council for Culture, Arts and Letter, 1983.

Ibn al-Haytham. Kitāo Fì Hall Shukūk Kitāb Uqlīdis fì alUșūl wa Sharh Ma 'ānīhi (facsimile edition). Frankfurt: 
Institut for the History of Arabic-Islamic Science at the Johann Wolfgang Goethe University, 1985.

Ibn al-Haytham. "Risālah Aḍwā' al-Kawākib." Dalam Majmū' al-Rasā'il li al-Hasan ibn al-Hasan ibn al Haytham. Hyderabad: Dā'irah al-Ma'ārif al'Uthmānīyah, 1938; repr., Frankfurt: Institute for the History of Arabic-Islamic Science at the Johann Wolfgang Goethe University, 1998.

Lane, Edward Willian. Arabic-English Lexicon, vol. 4 (8 vol.). Beirut: Librairie du Liban, 1968.

Leaman, Oliver. History of Islamic Philosophy, ed.Seyyed Hossein Nasr dan Oliver Leaman. London: Routledge Taylor \& Francis Group, 1996.

Al-Nasafì, Najm al-Dīn. 'Aqā'id al-Nasafì, terj. ed. Syed Muhammad Naquib al-Attas, The Oldest Known Malay Manuscript A $16^{\text {th }}$ Century Malay Translation of the 'Aqāid of al-Nasafí. Kuala Lumpur: Department of Publication University of Malaya, 1988.

Nasr, Seyyed Hossein. Three Muslim Sages. Delmar NY: Caravan Books, 1976.

Nasr, Seyyed Hossein. An Introduction to Islamic Cosmological Doctrines. Great Britain: Thames and Hudson, 1978.

Polito, Nicholas Lo. "Abd al-Karīm al-Jîlī: Tawhịd, Transcendence and Immanence". Tesis Ph.D, University of Birmingham, 2010.

Al-Qifṭi. Jamāl al-Dīn Abī al-Ḥasan 'Alī ibn Yusūf. Tārikh al-Hukamā', ed. Julius Lippert. Leipzig: Dieterich'sche Verlagsbuchhandlung (Theodor Weicher), 1903.

Quraishi, M.F. dan Baarman, J. "Discourse on Light." Makalah, Ibn al-Haytham Proceedings of The Celebrations of 1000th Anniversary Hamdard National Foundation Pakistan. Karachi: Hamdard Academy, 1969.

Rashed, Roshdi. "The Celestial Kinematics of Ibn alHaytham," Arabic Sciences and Philosophy, 17, 2007. 
Ross, W.D. "Introduction". Dalam Aristotle Metaphysics vol. I. London: Oxford University Press, 1975.

Șā'id al-Andalusī. Tabaqāt al-Umam, terj. ed. Salem, Sema' an I. dan Kumar, Alok. Science in the Medieval World "Book of the Catagorie of Nations". Austin Tex: University of Texas Press, 1991.

Sabra, A.I. Ibn Al-Haytham Optics Books I-III on Direct

Vision, vol. 1 (2 vols.). London: The Warburg Institute, University of London, 1989.

Sayyid Yūsuf, Jum 'ah. "Ibn al-Haytham.” Dalam 'Ilm alNafs fì Turath al-Islāmi. Vol. 2. Kaherah: Al-Ma had al'Alamì li al-Fikr al-Islāmi, 1996.

Şeşen, Ramazan et. al. Catalogue of Manuscripts in the Köprülü Library Vol. II. Istanbul: Research Centre For Islamic History, Art And Culture, 1986.

Shamsi, F.A. "Properties of Triangles in Respect of Perpendiculars." Makalah, Ibn al-Haytham Proceedings of the Celebrations of 1000th Anniversary Hamdard National Foundation Pakistan. Karachi: Hamdard Academy, 1969.

Sorabji, Richard. "Infinite Power Impressed: The Transformation of Aristotle's Physics and Theology." Dalam Aristotle Transformed the Ancient Commentators and Their Influence, ed. Richard Sorabji. Itacha NY: Cornell University Press, 1990.

Soskice, Janet Martin. Philosophers and God, ed. John Cornwell and Michael McGhee. New York: Continuum, 2009.

Takeshita, Masataka. Ibn 'Arabi's Theory of the Perfect Man and Its Place in the History of Islamic Thought, terj. Harir Muzakki, Insan Kamil Pandangan Ibnu 'Arabi: Sebuah Disertasi. Surabaya: Risalah Gusti, 2005.

Al-Ṭālibī, 'Ammār Jam'̄̄. "Kitāb Thamarah al-Hikmah li Ibn al-Haytham Dirāsah wa Taḥqīq." Dalam Majallah Majma' al-Lughah al-'Arabiyah bi Dimashq April 73 
Usep Muhammad \& Wan Mohd Nor, "Falsafah Sains Ibn al-Haytham," Afkār Vol. 19 Issue 2 (2017):33-72

No. 2. Damsyik: Majma' al-Lughah al-'Arabiyah bi Dimashq, 1998.

Wan Mohd Nor Wan Daud. Budaya Ilmu Satu Penjelasan. Singapura: Pustaka Nasional Ltd., 2007; repr. Kuala Lumpur, Dewan Bahasa dan Pustaka, 1991. 
Usep Muhammad \& Wan Mohd Nor, "Falsafah Sains Ibn al-Haytham," Afkār Vol. 19 Issue 2 (2017):33-72 